\title{
„NEKAD SU MI ZNALI REĆI DA NISAM BOLJA OD SVOG SINA“ - STIGMA OBITELJI TEMELJEM INTELEKTUALNIH TEŠKOĆA ČLANA OBITELJI
}

\author{
MARKO BULJEVAC, ZDRAVKA LEUTAR \\ Studijski centar socijalnog rada Pravnog fakulteta Sveučilišta u Zagrebu, kontakt: mbuljevac@pravo.hr
}

Primljeno: 11.04.2017.

Izvorni znanstveni rad

Prihvaćeno: 21.06.2017.

UDK: $364.28-056.34$

\begin{abstract}
Sažetak: Rad se bavi stigmom obitelji temeljem intelektualnih teškoća člana obitelji. Cilj ovog istraživanja bio je dobiti uvid u perspektive članova uže obitelji osoba s različitim stupnjem intelektualnih teškoća o stigmi obitelji temeljem intelektualnih teškoća. Istraživačko pitanje bilo je: „,Kako članovi obitelji osoba s intelektualnim teškoćama doživljavaju stigmu obitelji? “. Sudionici istraživanja bile se 22 osobe koje su članovi uže obitelji osoba s različitim stupnjem intelektualnih teškoća (10 majki, 3 oca, 2 sestre, 5 braće, 1 baka i 1 djed). Svi žive na području Grada Zagreba. Članovi njihovih obitelji s intelektualnim teškoćama su članovi ili korisnici udruga ili ustanova za osobe s intelektualnim teškoćama. U istraživanju se koristio kvalitativni pristup i metoda polustrukturiranog intervjua. Podaci su obrađeni interpretativnom fenomenološkom analizom. Dobiveni rezultati upućuju na stigmu obitelji koja se očituje kao: sažaljenje, okrivljavanje majki, braća i sestre koji trebaju preuzeti skrb za člana s intelektualnim teškoćama, omalovažavanje članova obitelji zbog člana s intelektualnim teškoćama, diskriminacija na radnom mjestu majki te život članova obitelji u izolaciji. Dobiveni rezultati su u skladu s ranijim istraživanjima s određenim specifičnostima upravo ovog istraživanja koje se odnose na gubitak statusa u društvu svih članova obitelji i umanjivanje njihove vrijednosti u socijalnim interakcijama. Za zaključiti je da stigma obitelji oblik boli i samoće.
\end{abstract}

Ključne riječi: stigma obitelji, članovi obitelji osoba s intelektualnim teškoćama, gubitak socijalnog statusa

\section{UVOD}

Stigma obitelji podrazumijeva internalizirane osjećaje srama i straha da će osoba biti odbačena ili isključena od društva, te doživljene izravne diskriminacije članova obitelji osoba s intelektualnim teškoćama (Richardson i Fulton, 2011). Predstavlja stereotipno viđenje određene grupe ljudi (Burke, 2007), budući da su osobe s intelektualnim teškoćama i članovi njihovih obitelji poimani posebnom grupom unutar društva. Obitelji osoba s intelektualnim teškoćama marginalizirane su u društvu, a njihova je potreba za pomoći i podrškom samo djelomično zadovoljena (Bertelli i sur., 2011). Posljedica stigmatizirajućeg identiteta je gubitak socijalnog statusa (Westerholm i sur., 2006). Stigma obitelji temeljem intelektualnih teškoća člana obitelji sadrži ograničenja prema socijalnim interakcijama te povećava osjećaj abnormalnosti (Allen i Ciambrone, 2003), budući da obitelj ne zadovoljava društvene standarde "normalnosti"
(Carnevale, 2007). Manifestira se kroz izbjegavanje članova obitelji s članom s intelektualnim teškoćama (Burke, 2007; Hubert, 2010). Predstavlja raskid životnih odnosa s mrežom podrške te gubitak resursa i životnih šansi (Yang i sur., 2007), što naposljetku rezultira nemogućnošću imanja ,uobičajenog“ života (JCHR, 2008). Roditelji osoba s intelektualnim teškoćama ponekad ne mogu realizirati svoje socijalne uloge i biti prihvaćeni u društvu (Pelchat i sur., 2003), pa u određenim zajednicama izbjegavaju javno reći da imaju dijete s intelektualnim teškoćama (Edewor i sur., 2010; Hsiao i Van Riper, 2011). Drugi nerijetko ustupaju kada saznaju da je netko roditelj djeteta s intelektualnim teškoćama (Mickelson, 2001; Power, 2008).

Rezultati istraživanja o stigmi obitelji roditelja osoba s intelektualnim teškoćama ukazuju da se stigma manifestira kroz pripisivanje osjećaja srama, razočaranja, optuživanja i frustracije (Ho i Keiley, 2003; Tam i Cheng, 2005), ismijavanje i 
odbacivanje od društva (Power, 2008; Edwardraj i sur., 2010; Russell i Norwich, 2012; Ahmed i sur., 2013) te sažaljenje (Mickelson, 2001; Datta i sur., 2002; Ahmed i sur., 2013). Jedan od oblika stigme je izostanak podrške u odgoju djeteta s intelektualnim teškoćama (Pelchat i sur., 2009; Bertelli i sur., 2011). Roditelje stigmatiziraju članovi zajednice, zdravstveni stručnjaci i članovi obitelji (Mickelson, 2001; Ho i Keiley, 2003; Tam i Cheng, 2005; Crabtree, 2007).

Majke češće doživljavaju stigmatizaciju nego li očevi (Forbat i Service, 2005; Sarkar, 2010; Edwardraj i sur., 2010; Russell i Norwich, 2012) koja se manifestira kroz ograničenu socijalnu podršku (Ahmed i sur., 2013), socijalnu isključenost (Griffith i sur., 2011), optuživanje za intelektualne teškoće djeteta (Alvarez McHatton i Correa, 2005; Gill i Liamputton, 2011; Ahmed i sur., 2013), oduzimanje nade u svjetliju budućnost (McHatton i Correa, 2005; Hubert, 2010) i sažaljenje (McGraw i Walker, 2007). Stigmatizira ih se nerealnim i pretjerano zaštitnički nastrojenima (Hubert, 2010). Rezultat stigme je izolacija u vlastiti dom kako bi se izbjegla dodatna stigmatizacija (Azar i Badr, 2006; Griffith i sur., 2011).

Malobrojni rezultati istraživanja o stigmi obitelji očeva ukazuju na njihov osjećaj srama i razočaranja (Crabtree, 2007). Očevi žele da im dijete bude percipirano „,normalnim“ (Pelchat i sur., 2003) jer im usporedba djeteta s djecom bez intelektualnih teškoća predstavlja stres koji je povezan s marginalizacijom i stigmatizacijom (Pelchat i sur., 2009). Razlog malog broja istraživanja o ovom segmentu stigme obitelji je izostanak uključenosti očeva u skrb o djetetu s intelektualnim teškoćama (McHatton i Correa, 2005; Azar i Badr, 2006; Power, 2008; Edwardaj i sur., 2010; Hubert, 2010). Roditelji se suočavaju sa stigmom negiranjem intelektualnih teškoća djeteta (Ho i Keiley, 2003; McHatton i Correa, 2005), izbjegavanjem kontakata (McHatton i Correa, 2005), ograničavanjem aktivnosti izvan vlastitog doma te izoliranjem od okoline (Azar i Badr, 2006; Ahmed i sur., 2013). Socijalna izolacija služi kako bi sebe i djecu zaštitili od vanjskih informacija i stigmatizacije koji pogoduju razvoju negativnih osjećaja (Edewor i sur., 2010; Hubert, 2010), ali i mogućih konfron- tacija s ostalima u društvu i straha od odbacivanja (Bertelli i sur., 2011).

Braća i sestre također mogu biti stigmatizirani zbog krvne veze s osobom s intelektualnim teškoćama (Burke, 2010). Istraživanja o stigmatizaciji braće i sestara osoba s intelektualnim teškoćama ukazuju da se oni bore sa saznanjem da su intelektualne teškoće stigmatizirajuća socijalna pozicija (Stalker i Connors, 2004; McGraw i Walker, 2007). U istraživanju McGrawa i Walkera (2007) sestre navode da su se braća sramila braće s intelektualnim teškoćama, očevi su bili prezaposleni, a one su se više osjećale majkama nego li sestrama. Rezultati istraživanja Burkea i Fella (2007) pokazuju da 51,8\% roditelja smatra da je dijete bez invaliditeta doživjelo nejednakosti zbog toga jer ima brata ili sestru s intelektualnim teškoćama, $56 \%$ da je imalo ograničene socijalne aktivnosti, $24 \%$ da je dobilo manjak pažnje od roditelja, dok ih je $6 \%$ bilo zadirkivano. Stigma obitelji kod braće i sestara uzrokuje sram, bijes, socijalnu izolaciju (Mandleco i sur., 2003; McGraw i Walker 2007), negativne odnose s vršnjacima (Burke, 2010), ali i povećanu kooperativnost i samokontrolu braće i sestara (Mandleco i sur., 2003; McGraw i Walker 2007). Kao iskustva stigmatizacije navode ismijavanje, sram i zadirkivanje (Naylor i Prescott, 2004; Stalker i Connors, 2004). Najizraženija stigma obitelji je pretpostavljena dužnost o skrbi za braću ili sestre s intelektualnim teškoćama tijekom cijelog života, koja se osobito nameće sestrama (Wagner Jakab i sur. 2006; Burke i Fell, 2007; McGraw i Walker, 2007; Davys i sur., 2010; Graff i sur., 2012).

Stigma obitelji rezultira uništavanjem socijalnih odnosa i utječe na poimanje samoga sebe (Mickelson, 2001). Rezultira da su obitelji osoba $\mathrm{s}$ intelektualnim teškoćama stigmatizirane, marginalizirane i isključene iz svojih lokalnih zajednica. Međutim, kao najveća posljedica stigme obitelji pojavljuje se osjećaj straha i zabrinutosti za budućnost osobe s intelektualnim teškoćama (Ho i Keiley, 2003; Pelchat i sur., 2009; Ahmed i sur., 2013). Predstavlja socijalni konstrukt invaliditeta jer objektivno invaliditet kod članova obitelji bez intelektualnim teškoćama ne postoji, iako ih se diskriminira temeljem percepcije različitosti (Burke, 2010). Osnovni konceptualni model stigme ovog rada bio je model Linka i Phelanove (2001) prema 
kojem je stigma koncept kada elementi etiketiranja, stereotipiziranja, odvajanja, gubitka statusa i diskriminacije koegzistiraju u situacijama moći koje omogućuju njihov daljnji razvoj i širenje.

\section{CILJ ISTRAŽIVANJA}

Cilj istraživanja bio je dobiti uvid u perspektive članova uže obitelji osoba s različitim stupnjem intelektualnih teškoća o stigmi obitelji temeljem intelektualnih teškoća člana obitelji. Sukladno cilju istraživanja definirano je sljedeće istraživačko pitanje: „Kako članovi obitelji osoba s različitim stupnjem intelektualnih teškoća doživljavaju stigmu obitelji?“.

\section{METODE}

\section{Sudionici}

Sudionici istraživanja bile su 22 osobe koje su članovi uže obitelji osoba s različitim stupnjem intelektualnih teškoća. Svi žive na području Grada Zagreba. Članovi njihovih obitelji s intelektualnim teškoćama su članovi ili korisnici udruga ili ustanova za osobe s intelektualnim teškoćama. Broj sudionika rezultat je spremnosti osoba da sudjeluju u istraživanju i primjene kriterija teorijskog zasićenja. Prilikom odabira sudionika poštivani su sljedeći kriteriji: procijenjeni su kvalitetnim informatorima od zaposlenika udruga i ustanova, njihova punoljetnost i punoljetnost člana obitelji $\mathrm{s}$ intelektualnim teškoćama, učestalost kontakata $\mathrm{s}$ članom obitelji s intelektualnim teškoćama te da su članovi obitelji osoba s različitim stupnjem intelektualnih teškoća.

U istraživanju je sudjelovalo 10 majki, 3 oca, 2 sestre, 5 braće, 1 baka i 1 djed. Najmlađi sudionik imao je 24 godine, dok najstariji 86 godina života. Prosječna dob sudionika bila je 56,63 $(\mathrm{SD}=16,53)$. Sudionici su članovi obitelji 5 žena i 13 muškaraca $\mathrm{s}$ intelektualnim teškoćama. Kod 1 sudionika član obitelji je osoba s lakim intelektualnim teškoćama, 14 sudionika članovi su obitelji osobe s umjerenim intelektualnim teškoćama, 2 sudionika obitelji osobe s težim intelektualne teškoće, dok je kod 5 sudionika član obitelji osoba s teškim intelektualnim teškoćama. Prosječna dob člana obitelji s intelektualnim teškoćama je 34,09 godina života $(\mathrm{SD}=7,01)$.
Tablica 1. Sociodemografski podaci o sudionicima članovima obitelji osoba s različitim stupnjem intelektualnih teškoća

\begin{tabular}{|c|c|c|}
\hline $\begin{array}{l}\text { Sociodemografski } \\
\text { podaci }\end{array}$ & Kategorija & $\mathbf{N}$ \\
\hline Spol & $\begin{array}{l}\text { Ženski } \\
\text { Muški }\end{array}$ & $\begin{array}{l}13 \\
9\end{array}$ \\
\hline Dobni razred & $\begin{array}{l}24-30 \\
31-40 \\
41-50 \\
51-60 \\
61-70 \\
71-86\end{array}$ & $\begin{array}{l}2 \\
2 \\
2 \\
6 \\
7 \\
3\end{array}$ \\
\hline $\begin{array}{l}\text { Postignuti stupanj } \\
\text { obrazovanja }\end{array}$ & $\begin{array}{l}\text { NKV } \\
\text { KV } \\
\text { SSS } \\
\text { VŠS } \\
\text { VSS }\end{array}$ & $\begin{array}{l}2 \\
1 \\
11 \\
2 \\
6\end{array}$ \\
\hline Radni status & $\begin{array}{l}\text { Student } \\
\text { Zaposlen } \\
\text { Nezaposlen } \\
\text { Umirovljenik } \\
\end{array}$ & \begin{tabular}{|l}
2 \\
4 \\
4 \\
12
\end{tabular} \\
\hline Bračni status & $\begin{array}{l}\text { Samac } \\
\text { Bračna zajednica } \\
\text { Razveden/a } \\
\text { Udovac }\end{array}$ & $\begin{array}{l}4 \\
11 \\
3 \\
4\end{array}$ \\
\hline Tip kućanstva & $\begin{array}{l}\text { Samac } \\
\text { Dvogeneracijska obitelj } \\
\text { Trogeneracijska obitelj }\end{array}$ & $\begin{array}{l}2 \\
15 \\
5\end{array}$ \\
\hline $\begin{array}{l}\text { Učestalost } \\
\text { kontakata s članom } \\
\text { s intelektualnim } \\
\text { teškoćama }\end{array}$ & $\begin{array}{l}\text { Svakodnevno } \\
\text { Jednom do nekoliko puta tjedno }\end{array}$ & $\begin{array}{l}18 \\
4\end{array}$ \\
\hline
\end{tabular}

\section{Postupak prikupljanja podataka}

Podaci su prikupljeni metodom polustrukturiranog intervjua. Pilot istraživanje provedeno je s majkom i sestrom osobe s umjerenim intelektualnim teškoćama, koje kasnije nisu sudjelovale u istraživanju. Prije provedbe istraživanja dobivena je suglasnost Etičkog povjerenstva Pravnog fakulteta Sveučilišta u Zagrebu. Istraživanje je provođeno od mjeseca srpnja 2013. godine do mjeseca veljače 2014. godine. Intervjui su provođeni sukladno odabiru sudionika u njihovom domu, udruzi/ ustanovi ili na radnom mjestu istraživača. Svaki intervju proveden je prostoriji u kojoj su bili samo sudionik $i$ istraživač. Prosječno trajanje intervjua iznosilo je 38,88 minuta. Tijekom provedbe i po završetku istraživanja pridržavalo se sljedećih etičkih načela: predstavljanje istraživača sudionicima istraživanja, stvaranje odnosa povjerenja između sudionika 
$\mathrm{i}$ istraživača, postavljanje granica u odnosu sudionika i istraživača, upoznavanje sudionika s istraživanjem, pismeni i usmeni informirani pristanak, povjerljivost i anonimizacija podataka, odgovaranje tijekom i odustajanje od intervjua, briga o emocijama sudionika tijekom i poslije intervjua, upoznavanje sudionika s rezultatima istraživanja, otvorena mogućnost drugog intervjua te nagrađivanje sudjelovanja u istraživanju.

\section{Obrada podataka}

Podaci su obrađeni interpretativnom fenomenološkom analizom koja uključuje fenomenološki pristup utemeljen na detaljnom ispitivanju sudionikovog svijeta, s ciljem saznanja kako pojedinci poimaju određene situacije s kojima se susreću i na koji način daju smisao svom osobnom i socijalnom svijetu iz individualne perspektive (Smith i Osborn, 2003). Detaljna analiza osobnih doživljaja sudionika povezana je s osobnom interpretacijom istraživača, budući da se tijekom procesa analize uzimaju u obzir i sudionikove i istraživačeve interpretacija istraživanog fenomena (Smith i Osborn, 2003; Pietkiewicz i Smith, 2012). Prvo sudionici daju značenje svijetu koji ih okružuje, a potom istraživač pokušava dekodirati dobivena značenja od sudionika (Pietkiewicz i Smith, 2012). Interpretativna fenomenološka analiza se temelji na ideografskom pristupu i detaljnoj analizi svakog slučaja s ciljem pružanja detaljnog uvida u percepcije i razumijevanja određene grupe prema istraživačkom fenomenu bez generaliziranih tvrdnji i zaključaka (Smith i Osborn, 2008). Induktivna je metoda (Reid i sur., 2005).

Interpretativna fenomenološka analiza se sastoji od sljedećih koraka: višekratno interpretativno čitanje prvog slučaja s bilježenjem inicijalnih ideja iz teksta, identificiranje i kodiranje značajnih inicijalnih izjava, uz moguće bilježenje inicijalnih interpretativnih komentara. Značajne inicijalne izjave se potom modificiraju u teme koje proizlaze iz odgovora. Istraživač potom ispituje teme i utvrđuje poveznice između njih, s time da će se neke teme međusobno povezati, dok će druge ostati zasebne cjeline. Finalni rezultat analize su nadređene teme objašnjene podređenim temama. Nadređene teme služe kako bi se napravili hijerarhijski odnosi između tema. Proces se vrši zbog strukturiranja i organiziranja podataka, budući da je cjelokupni transkript temeljni izvor informacija i rezultata. Na kraju se dobiveni individualni obrasci, dakle provedene analize za svaki pojedini transkript, međusobno dovode u svezu i grupiraju u veliku zajedničku tablicu nadređenih tema na način da se kompariraju ili se pak naglašava kontrast između njih.

Najvažniji kriteriji valjanosti i pouzdanosti rezultata su unutarnja dosljednost i prezentacija objašnjenja na način da se čitatelju omogući da samostalno preispita istraživačeve interpretacije kroz ponuđene citate izjava sudionika u radu (Smith, 1996). Pouzdanost se može postići maksimalnim pridržavanjem protokola intervjua i činjenjem minimalnih varijacija u vlastitom ponašanju za vrijeme različitih intervjua (Smith i Osborn, 2008).

\section{REZULTATI}

Temeljem analize perspektiva članova obitelji utvrđeno je šest tema vezanih za stigmu obitelji temeljem intelektualnih teškoća člana obitelji.

Tablica 2. Nadređene i podređene teme o stigmi obitelji

\begin{tabular}{|l|l|}
\hline NADREĐENE TEME & PODREĐENE TEME \\
\hline Sažaljenje & $\begin{array}{l}\text { Krivnja zbog ne prekidanja } \\
\text { rizične trudnoće } \\
\text { Intelektualne teškoće } \\
\text { naslijeđene su od majčine } \\
\text { obitelji }\end{array}$ \\
\hline Okrivljavanje majki & $\begin{array}{l}\text { Braća i sestre trebaju } \\
\text { preuzeti skrb }\end{array}$ \\
\hline $\begin{array}{l}\text { Omalovažavanje osobe } \\
\text { zbog člana obitelji s } \\
\text { intelektualnim teškoćama }\end{array}$ & $\begin{array}{l}\text { Član s intelektualnim } \\
\text { teškoćama predstavlja temelj } \\
\text { identiteta obitelji } \\
\text { Poistovjećivanje s članom s } \\
\text { intelektualnim teškoćama } \\
\text { Očinstvo sramotnog djeteta }\end{array}$ \\
\hline $\begin{array}{l}\text { Diskriminacija na } \\
\text { radnom mjestu majki }\end{array}$ & $\begin{array}{l}\text { Nemogućnost profesionalnog } \\
\text { usavršavanja } \\
\text { Degradiranje na radnom } \\
\text { mjestu } \\
\text { Radna neupotrebljivost } \\
\text { majke nakon rođenja djeteta s } \\
\text { intelektualnim teškoćama }\end{array}$ \\
\hline Život u izolaciji & $\begin{array}{l}\text { Nepoželjno društvo } \\
\text { Osamljivanje } \\
\text { Prepuštenost samom sebi } \\
\text { Neizvjesnost }\end{array}$ \\
\hline
\end{tabular}




\section{Sažaljenje}

Sažaljenje kao nadređena tema nije pojašnjavano dodatno podređenim temama zbog jasnoće navedenog iskustva kao jednog od najčešćih oblika stigme obitelji kojeg su doživjeli i sudionici ovog istraživanja. Iako su bili sažalijevani, pomoć i podrška nisu im bile pružene: ,, Jadna ti. Ali samo to. Kažu - jadna ti, ali ništa da onda indirektno na neki način pomognu. Ne, nego dapače imam osjećaj da me još više gurnu da ne kažem gdje. (2-1) “ ili „, Općenito nas tam na kvartu gdje smo živjeli, susjedi ti naši koji čak ni nisu s nama razgovarali su sažalijevali - joj kaj bu tek sad, ona jadna jedina radi, ovaj je bolestan. Tko zna kakav bu i ovaj ispao, kaj bu od njega bilo. U tom stilu - vidi ih, jadni su i bez oca ostali. Nikad nitko nije došao $i$ rekao treba li vam pomoć (smijeh). Sve je super što je daleko. (2-17) “. Iskustva upućuju kako u suštini sažalijevanje predstavlja razlikovanje, koje u sebi sadrži separaciju od drugačijeg i nepoželjnog. Sažaljenje isto tako vrijeđa osobu: ,, Gospođa mi je jedna rekla u jednoj firmi gdje sam radio. Prva firma u kojoj sam radio. Prišla mi je, što mi je bilo totalno malo začuđujuća ta izjava: ja mislim u biti da si ti jako zakinut u svom životu jer imaš tog brata (pauza). Znači ne bi li bilo bolje da se riješite tog brata, bilo bi ti lakše u životu- to sam očekivao da će reci sljedeće. Njezina prva rečenica je bila u tom tonu. Nisi li ti zakinut u životu zbog svog brata? Malo je falilo da joj puknem šamar. Rekao sam, gospođo nemate pojma o čemu pričate, okrenuo sam se i otišao. (2-17) “. Doživljene emocije vezane uz sažaljenje sudionik opisuje sljedećim metaforama: iznenađenost „totalno malo začuđujuća izjava“, bijes „malo je falilo da joj puknem šamar", povrijeđenost ,nemate pojma o čemu pričate" te zadržavanje prisebnosti odlaskom. Radi se o događaju gdje je sudionik bio u podređenom položaju od osobe koja ga je stigmatizirala, jer se radilo o radnom mjestu gdje se tek zaposlio.

\section{Okrivljavanje majki}

Stigma obitelji manifestirala se i kao okrivljavanje kroz imputiranje odgovornosti, budući da su osobe iz uže i šire okoline otvoreno prozivali majke za odgovornost.

\section{Krivnja zbog neprekidanja rizične trudnoće}

Odluka o neprekidanju rizične trudnoće poslužila je kao temelj stigmatizacije majki. Stigmatizirale su ih članice obitelji, koje su i same bile majke: „,Moja me sestra pitala zašto sam ga rodila. Da. Jer ja sam znala da će biti downovac jer sam bila na amniocintezi. Nalazi su došli, čekalo se jako dugo, bila sam 6 mjeseci trudna. Teško je bilo se odlučit za pobacit i znala sam što će biti. I onda je bio komentar malo kasnije da se čude zašto sam ga uopće rodila. Teško je to odlučiti se. Moja sestra mi je to rekla nakon par godina. Šogorica, ona koja je ortodoksni katolik, ona mi je rekla: i katolička vjera dopušta pobačaj u takvom slučaju. (2-20) “. Osim prozivanja od vlastite sestre, sudionica navodi i stigmatizaciju od šogorice koju opisuje „ortodoksnim katolikom“ aludirajući da je rečeno u potpunoj suprotnosti s proklamiranim načelima života osobe. Navedeno ukazuje i na nepoštivanje odluke sudionice. Navodeći sintagmu „teško je bilo odlučiti se" sudionica dodatno želi naglasiti kako samo razmišljanje o prekidu trudnoće sadrži etičke dileme i da je emocionalno zahtjevno. Međutim, zdravstveni sustav je posredno smatran odgovornim za stanje djeteta, budući da sudionica koriste sintagme „nije uspjela amniocinteza, zakazala je profesorica“ te ,nalazi su došli, čekalo se jako dugo". U istraživanju je druga sudionica iznjela vrlo slično iskustvo, temeljem čega se može zaključiti sljedeće: u obje situacije stigmatizirane su majke djeteta s Down sindromom, stigmatizirale su ih sestre i šogorica, pripadnice iste generacije uspravne i pobočne obiteljske linije. Budući da su sudionice rodile dijete kao rodilje starije od 35 godina života, možda je razlog stigmatizacije bio iskazivanje vlastite genetske uspješnosti pred drugim članovima obitelji ili pak strah od rođenja novog člana s intelektualnim teškoćama u nekoj od drugih generacija obitelji.

\section{Intelektualne teškoće naslijeđene su od majčine obitelji}

Iskustva drugih dviju majki ukazuju da im je pripisivana krivnja zbog genetskog nasljeđa koje su ,prenijele“ djetetu: ,, Oni su stalno, okrivljavali su me tko zna čiji je, je li moje narodnosti ili nije. Ne. Nisu ga prihvatili. To mogu reći, i mogu pred 
mužem reći. Čak su zvali telefonom i što nekad nisam ni prenosila mužu i ispitivali tko je u mojoj familiji ovakav, onakav, takav kao sin. Ja sam bila krivac, da. To je tako od početka. Ja sam iz druge države, ja ću vam odmah reći. To vam je odmah stepenicu, 5 stepenica dole u njihovim glavama. Briga me, ali ja sam ja (smijeh) (2-11) “. Sintagma „okrivljavali su me tko zna čiji je“ dočarava sumnju u vjernost majke suprugu i dovodi u upitnost očinstvo djeteta, dok je centralni dio doživljene stigme povezan s narodnošću majke. Naime, majka je osoba iz države čiji se stanovnici u hrvatskom društvu često ismijavaju i koriste kao sinonim za manje vrijedne ljude, pa su članovi suprugove obitelji stigmatizirali i kroz prozivanje tko je još u njenoj porodici takav kao i član s intelektualnim teškoćama. Time su iskazivali i uvjerenost u superiornost vlastitog obiteljskog nasljeđa. Slično iskustvo doživjela je i sljedeća majka: „, I još jednu rečenicu koju sam čula nekoliko puta koja mi je jako pogodila. U našoj obitelji nema nitko takav. Znate. (2-16) “. Nesavršenost majčine obitelji jasno naglašava sintagma „u našoj obitelji nema nitko takav", dok je polemiziranje pred drugim ljudima o majčinoj odgovornosti za stanje djeteta pokazatelj dodatnog etiketiranja sudionice. Oba navedena stigmatizirajuća iskustva sadrže tri zajedničke odrednice: majke su drugih narodnosti nego li očevi, stigmatizirane su bile prvenstveno od ženskih članova obitelji, te im supruzi nisu pružili podršku i zaštitu u tim trenucima, već su se priklonili svojim primarnim obiteljima.

\section{Braća i sestre trebaju preuzeti skrb}

Navedeno također zbog jasnoće nije dodatno objašnjeno podređenim temama. Iako veliki dio sudionika zbog doživljene stigmatizacije nema očekivanja od osoba iz svoje okoline, nekoliko sudionika podijelilo je svoja iskustva koja upućuju na nametanje određenih uloga od članova svoje uže obitelji. Dio sudionika roditelja su naveli zabrinutost i strah što će biti s njihovim djetetom ukoliko se teže razbole ili nakon njihove smrti, što može predstavljati nametanje uloge potencijalnih skrbnika i njegovatelja braći i sestrama: ,, Što je jako dobro jer znam druge roditelje ovaj koji govore ah on ima tu i tu sestru koja će završiti takav fax i njemu je sve poklopljeno. Ja bi čak više htjela brinuti o njemu nego što bi zapravo moja mama npr. htjela da se brinem. Ovaj tak da ovo podržava da odem, nađem si muža tako. (2-8) “. Dok su sudionicu stigmatizirali roditelji bratovih prijatelja kroz etiketiranje nje kao nasljednice skrbi o bratu zbog zvanja koje je pomažuće struke koristeći metaforu „njemu je sve poklopljeno“, jedna majka je vrlo otvoreno priznala stigmatizaciju svog drugog sina bez intelektualnih teškoća: „Nekada bi pomislila da taj mladi brat njegov ne voli dovoljno. Onda sam čak i pratila i gledala pa da li njemu smeta što je on takav. I to je nekako tako trajalo, ta moja neka razmišljanja. Ja bih ovako s njim ponekad porazgovarala: vrijeme vidiš prolazi, rastete, odrastate, jednog dana neće biti mene, trebat će neko o njemu brinut. On je meni rekao, znaš, mislim da ja neću moći brinuti o njemu (pauza). Da, ja to neću moći. Ja sam rekla - dobro, u redu, vidjet ćemo što će biti, ali stalno sam mislila da nije red da ja opterećujem mladega da on sada mora o njemu voditi brigu i da ja njemu ostavljam na teret. To sam uvijek mislila o tome, a u isto vrijeme je bila želja da se oni zbliže što više i da on ipak računa na to da mora o njemu brinuti. (2-16) ". Sudionica je navela da se odlučila za drugo dijete kada je sin s intelektualnim teškoćama imao 4 godine, što odgovara vremenu kada je po prvi puta primijetila i bila upozorena na odstupanja u razvoju djeteta. Dok je suprug pokazao indiferentan stav prema ideji drugog djeteta, ideja i želja je bila isključivo majčina jer nije htjela da joj sin s intelektualnim teškoćama ostao sam. Time aludira na zabrinutost za budućnost djeteta. Majka koristi metaforu „ostavljati na teret" kao opis relacije njezine odluke da skrb prepusti sinu, dok metaforu „računa na to“ na nametnutu obvezu preuzimanja skrbi o bratu. Na kraju intervjua sudionica je navela kako se danas pokušava iskupiti sinu bez intelektualnih teškoća zbog toga jer ima osjećaj da mu nije pridavala dovoljno pažnje dok je odrastao.

\section{Omalovažavanje osobe zbog člana obitelji s intelektualnim teškoćama}

Iskustva sudionika pokazuju da su u nekim situacijama bili poimani isključivo kroz člana obitelji s intelektualnim teškoćama. Identifikacija cijele obitelji temeljem člana s intelektualnim 
teškoćama služi etiketiranju obitelji drugačijom i onom koja ne udovoljava normama kakva bi obitelji trebala biti.

\section{Član s intelektualnim teškoćama predstavlja temelj identiteta obitelji}

Dvoje braće opisuju da su bili identificirani od osoba iz okoline kao pripadnici obiteljske loze koja je bolesna: ,, Onda je bilo priče, kao ono, taj mali ti je iz one kuće s bolesnim. Ta priča recimo, što su susjede neke i tak, to je bila priča (2-10) " te „I to je sistem, onako - dobar dan, kako ste, i to je naš razgovor. Ništa više od toga. Samo onako pitanje, aha vi imate onog brata koji je bolestan. Onda ja rekao da. Aha. I na to se svode razgovori. (2-17) “. Sudionik je ovog puta bio identificiran isto tako kao osoba s bolesnim bratom, čime krvna veza s osobom s intelektualnim teškoćama postaje glavno identifikacijsko, ali i razlikovno obilježje od ostalih u društvu.

\section{Poistovjećivanje s članom s intelektualnim teškoćama}

Poistovjećivanje s članom s intelektualnim teškoćama služi iskazivanju da je osoba isto tako smanjenih intelektualnih kapaciteta, ali i vrijeđanju: „Ah (pauza) nekad su mi znali reći da nisam bolja od svog sina. (2-11) “ ili „, Brat je boleština i ti si sigurno bolestan (2-17) “. Doživljeno je i ponižavanje, gdje je osoba tretirana kao i član obitelji s intelektualnim teškoćama: ,, I zadirkivali su $i$ mene i njega su stavljali u isti razred što bi trebalo biti bez obzira na sve. Bilo je imaš brata debila. Bilo je baci mu loptu u glavu, pa onda drugi baci meni u glavu i tako je nastalo dok nisam skočio $i$ oni se povukli. Brat se povukao dokja nisam skočio, kad je vidio da se mi tučemo onda se on išao tuči (smijeh). Iako nije znao, tukao se (smijeh). (2-17) “. Bacanje lopte u glavu predstavlja ponižavanje osobe, s time da je sudionik racionalizirao iskustvo: „, Kad sam bio klinac pasalo mi je jer mi je dizalo ego. Svaki put kad bi nas netko malo gazio ja bi više rastao. (2-17) ".

\section{Očinstvo sramotnog djeteta}

Dok iskustva sudionika ovog istraživanja ukazuju da su majke najčešće doživljavale stigmatiza- ciju od stručnjaka i ženskih članova obitelji, dvoje očeva stigmatizirale su kolege. Prilikom verbalnog sukoba s kolegom sudionik je doživio: „Bilo je jedan poslovni sukob, baš poslovni. Gdje u verbalnom deliktu sam bio grubo izvrijeđan, kakje nastao taj sukob verbalni, gdje sam ja u jednom određenom trenutku mi se reklo (pauza) asociralo na mene kao oca idiota. To je u podsvijesti ljudi još uvijek, a u ono vrijeme, a ja mislim i danas, da je to bilo u podsvijesti ljudi ugrađeno. Ta različitost. (2-15) “. Iako sudionik navodi da je stvar u različitosti, vrijeđanje roditelja kroz djecu je bolno. Isticanje sramotnosti djeteta služi isticanju drugačijeg očinstva, ali i iskazivanju uvjerenja o neuspjehu reprodukcije osobe. Drugi otac doživio je prijetnju da će svi saznati da je otac djeteta s određenim sindromom: ,, Kad su bili izbori za jedno mjesto jedne godine, kolega se zaprijetio mom suprugu da, zaprijetio rekao da se ne kandidira, da ga neće podržati, a ako se bude, da će izaći u javnost da ima dijete s poteškoćama. Uglavnom, da će izaći u javnost. Veli muž, ja se ne sramim njega, mi se nikad nismo njega sramili. Suprug se nije obazirao na to, ali pogodi te. (2-20) “.

\section{Diskriminacija na radnom mjestu majki}

Diskriminaciju na radnom mjestu, kao iskustvo stigme obitelji, navele su samo majke osoba s intelektualnim teškoćama.

\section{Nemogućnost profesionalnog usavršavanja}

Pravo na stjecanje novih poslovnih znanja i osporavano je sudionici: „Gledajte ja sam završila VSS i po pravilniku me firma mora na usavršavanje poslati. Nikada me nije poslala na usavršavanje zbog djeteta. Onda se desilo da smo dobili kompjutere, svi su išli ja nisam opet išla zbog djeteta. (2-1) “. Navedeno iskustvo ukazuje na izuzetno perfidan oblik stigmatizacije, budući da se radi o pravo čiju realizaciju većina poslodavaca ne osigurava svojim zaposlenicima. Stigmu obitelji majka je dodatno objasnila „Po njima bolesno dijete, znači nemam nikakva prava da idem na nekakva usavršavanja, skupove. (2-1) " što dovodi do zaključka da se upravo stanje djeteta povezivalo s bolešću koja sama po sebi implicira neophodnost stalne skrbi majke. 


\section{Degradiranje na radnom mjestu}

Majčinstvo djeteta s intelektualnim teškoćama rezultiralo je gubitkom statusa u radnoj okolini: „Odmah su me anulirali s radnog mjesta na kojem sam bila. Spustili su me s radnog mjesta. Bilo je jako teških situacija. Mislim meni osobno, ovaj $i$ po jednoj strani vas žale kao, a po drugoj strani jednostavno i intelektualno ponižavaju. To je tako. I šefovi i kolege. To je tako. (2-11) “. Gubitak prestižnijeg mjesta u hijerarhiji rada opisan je sintagmom „spustiti s radnog mjesta“, dok se diskriminacija opisuje pojmovima degradirati, ponižavati i žaliti koji u sebi oslikavaju zauzetu poziciju moći osoba iz radnog kolektiva.

\section{Radna neupotrebljivost majke nakon rođenja djeteta $s$ intelektualnim teškoćama}

Možda najradikalniji primjer diskriminacije na radnom mjestu je otkaz ugovora o radu, te nemogućnost ponovnog zaposlenja: , Kad sam rodila njega sam dobila otkaz. Komentar je bio da bit će on bolestan često i neću moć bit toliko na poslu. Neću moći biti na poslu (pauza i uzdah). Ja sam tamo odradila 20 godina. I bili smo, ta šefica mi je bila više nego dobra. (2-20) “. Sudionica navodi stigmatizaciju vlastite radne učinkovitosti temeljem rođenja djeteta s Down sindromom, koji je uočljiv odmah po rođenju, iako je navela kako je s poslodavcem imala intenzivan privatno- poslovni odnos. Budući da je spomenula kroz razgovor pranje stubišta kao bolju soluciju nego li povrataka kod istog poslodavca, može se zaključiti povrijeđenost koja je rezultirala ponosom kod sudionice.

\section{Život u izolaciji}

Veliki dio sudionika opisao je život u izolaciji. Kao što rezultati istraživanja ukazuju, izolacija se ne odnosi na socijalnu izolaciju, socijalnu isključenost ili pak separaciju, već svakodnevnicu obilježenu izolacijom od ostalih članova društva.

\section{Nepoželjno društvo}

Osjećaj nepoželjnosti zbog člana s intelektualnim teškoćama iskustvo je koje je rezultiralo postepenom izolacijom cijele obitelji od okoline. Brat navodi: ,, Velim primijetio sam kad smo išli u goste kod čak bliskih nam ljudi da je to bilo ono što nije falilo da kažu kad bute doma išli. Da, naravno, to neće reći, ali ja sam bio dovoljno mudar, i možda sam da se previše ne inkomodiram, možda sam bio i sebičan da čim prije završi agonija posjeta, pa onda ideš, ajde idemo doma. Ne bumo više te ljude zafrkavali. Idemo doma, mi budemo to lakše istrpjeli, budeš ti mama to istrpjela (misli na brata s intelektualnim teškoćama), jer ja bum tak i otišel navečer kad meni to dopizdi sve skupa. I tako. (2-10) “. Sudionik iznosi iskustvo vlastite odluke da se izolira od ostalih zbog obiteljske situacije, te koristi metafore „zafrkavati“ koje asociraju na osjećaj nepoželjnosti kao gosta te „istrpjeti“ koja se odnosi na ponašanje brata s intelektualnim teškoćama. Potrebno je naglasiti kako je ovaj sudionik više puta tijekom intervjua naglašavao $i$ opisivao koliko su mu druženja u životu važna.

\section{Osamljivanje}

Kao i u upravo navedenom iskustvu brata osobe $\mathrm{s}$ intelektualnim teškoćama, prema sljedećem ocu cijela obitelj osobe s intelektualnim teškoćama se zbog predrasuda počela osamljivati: „, Kak ću pitati susjeda za kojeg znam, dobar sam se njim, znam da su nam djeca išla zajedno u kino, ja sam ih vozio $u$ kino kad su bili manji, išli smo na izlete. Međutim kasnije ništa. I kako ću pitat zašto ti nećešs, kad u biti znam pozadinu zakaj je to puklo. Pozadina su moj sin i intelektualne teškoće.... Sve je prestalo. Sve je prestalo. (2-15) “. Samoća i težina izoliranosti u iskustvo ovog oca ogleda se ponavljanju „sve je prestalo“ i decidiranom naglašavanju da ga jedino smeta odvojenost. Kroz razgovor je sudionik detaljno opisao što je sve tijekom života učinio kako bi njegov sin bio prihvaćen u društvu osoba bez intelektualnih teškoća, dok metaforom „zakaj je to puklo“ sugerira na prekid kontakata i prijateljstava s članovima obitelji i prijateljima koji imaju djecu bez intelektualnih teškoća odrastanjem njihove djece. Iako nekoliko puta vrlo otvoreno navodi da je bila odluka supruge i njega da se osame od okoline, iz navedenog iskustva se može uočiti razočaranost oca i bol koju sadrži stigma obitelji. Također, osamljivanje je rezultat distanciranja osoba iz okoline od članova obitelji osobe $\mathrm{s}$ intelektualnim teškoćama zbog različitih načina života. 


\section{Prepuštenost samom sebi}

Potrebo je navesti da su upravo opisana iskustva povezana s prepuštenošću samom sebi iskustva isključivo samohranih majki: „Poslije suprugove smrti mi smo ostali sami. Doslovno sami. Dok je muž bio živ kuća je vječito bila puna. Tu su dolazili prijatelji, poznanici, rodbina. Najedanput svi su obećavali. Ljudi svi koji su bili dok je muž bio, sve se razišlo. Mislim, svi su oni više manje, sad ću bit zločesta, svi su oni došli tu razgovarat s mužem $i$ znali su da je na položaju. Prvo to, razgovara s njim, a i jesti, s oproštenjem, jer su bile večere. Prema tome to je to. Oni su imali svoju korist. Jedan mi je poslije suprugove smrti došao i rekao u oči: ti znaš da sada neće biti isto kao što je bilo dok je tvoj muž bio živ. Evo, mislim (pauza), on je još u oči mi to rekao, a drugi su se povukli. (2-20) ". Iako su navedene osobe iz okoline znale obiteljsku situaciju, majka je ostala sama s djecom neposredno nakon suprugove smrti. Sudionica koristi metaforu „povlačenje“ kako bi opisala da je ostala prepuštena sama sebi, ali i sintagmu ,ostati doslovno sam“ koja predstavlja napuštanje. Spominjanje koristi od druženja sa suprugom isto tako ukazuje na lažno prihvaćanje djeteta $\mathrm{s}$ intelektualnim teškoćama samo kako bi se ostvarila korist. Uz prepuštenost samom sebi dvoje sudionika navodi da su osobe iz okoline pružale lažna obećanja: ,, Uglavnom su obećanja, u kojima vidiš da nema realnosti. Tipa recimo ono što muči sve nas - što će biti poslije. Eh. Što s njim onda. Onda svako veli nema brige, ja ću se brinut. Vele mlađi ili njihova djeca. Ali tokom vremena vidiš da to nije to. (2-15) “. Tijekom intervjua se dobio dojam da je sudionik najviše zabrinut po pitanju budućnosti nakon što supruga i on preminu, te da se zbog lažnih obećanja mlađih članova obitelji i djece prijatelja separirao od njih. Nakon što je sudionik rekao navedeno, uslijedila je duga pauza i šutnja u razgovoru.

\section{Neizvjesnost}

Sudionica opisuje odsustvo ikakve garancije po pitanju skrbi za kćer: „Ono što mene kao roditelja jako zanima to je život mog djeteta nakon mene. “(2-3), dok jedan od očeva opisuje: „,Ja mislim da je to ovaj ta briga da se pretvorila $u$ jednu vrstu nije ovisnosti, bolesti. Pretjerane bole- sti, kako će ono, kako će ovo, što će bit poslije. Ne samo moja nego i kod supruge. Ja živim za inkluziju, grupu ljudi, i njega na to pripremamo. Ne ovisi o meni i mojoj supruzi već stupnju društva. Ja živim za to da se jednog dana formira grupica koja će moć samostalno djelovat. Čak sam išao toliko daleko i razgovarao sa suprugom. Sve ono što imam, pokretna i nepokretna. To ne ostaje meni. Ja nemam nasljednika. Igrom slučaja rodbina mi je takva da nemam povjerenja u nju. Tako da sam došao do zaključka danas sutra, sve moje ostaje društvu. Ja kad pričam sa suprugom što je day after, onda smo se dogovorili da ne pričamo o tome ona i ja, nego onaj koji ostaje zadnji da to rješava. I to je po meni rješenje. I na kraju krajeva kad si razmišljam o tome (misli na inkluziju), lakše spavam. Po meni je to rješenje. Ta inkluzija. Bez toga ne znam. Jer novac nije problem, novac nađeš za to čak i u obitelji. Svi mi imamo nešto. (2-15) “. Metafore „ovisnost“" i ,bolest“" oslikavaju stalnu preokupiranost neizvjesnošću tko će preuzeti skrb o sinu. Za pretpostaviti je kolika je zabrinutost oca koji naglašava kako društvo stigmatizira osobe $\mathrm{s}$ intelektualnim teškoćama i osporava im pravo na inkluziju, a istodobno je svjestan da će njegova imovina pripasti državi koja će kroz sustav socijalne skrbi preuzeti skrb o sinu.

\section{RASPRAVA}

Članovi obitelji kao prvi oblik stigme obitelji navode sažaljenje, koje je utvrđeno i u ranijim istraživanjima (Ahmed i sur., 2013) te je povezano $\mathrm{s}$ poistovjećivanjem brige o osobi s intelektualnim teškoćama teretom (Datta i sur., 2002), sramotom i tragedijom (Shaw, 2009). Okrivljavanje su kao oblik stigmatizacije doživjele majke osoba s intelektualnim teškoćama, budući da su bile prozivane od članica obitelji zbog ne prekidanja rizične trudnoće s djetetom s Down sindromom. Majke osoba $\mathrm{s}$ intelektualnim teškoćama često su prozivane zbog rođenja djeteta i ne prekidanja trudnoće (Ho i Keiley, 2003; Ahmed i sur., 2013). Ranija istraživanja isto ukazuju, kao i rezultati ovog istraživanja, na etiketiranje kako su intelektualne teškoće naslijeđene od majčine obitelji (McChaton i Correa, 2005; Edwardraj i sur., 2010; Bercker, 2011; Ahmed i sur., 2013). U istraživanju Sen i Yurtsever (2007) 17,1\% majki je izjavilo da su bile 
okrivljavane zbog stanja intelektualnih teškoća djeteta, te da ih je u 50\% slučajeva okrivljavao suprug. Međutim, rezultati ovog istraživanja ukazuju na sljedeće posebnosti ove stigmatizacije majki: majke su drugih narodnosti nego li očevi, stigmatizirane su bile od ženskih članova obitelji, te im supruzi nisu pružili podršku i zaštitu. Članicama obitelji koje su stigmatizirale je upravo rođenje djeteta bez intelektualnih teškoća osiguralo poziciju moći, dok su sudionice rođenjem djeteta s intelektualnim teškoćama doživjele gubitak statusa u obitelji.

Stigma obitelji doživljena je i kao nametanje braći i sestrama bez intelektualnih teškoća uloge njegovatelja i skrbnika, to jest preuzimanje skrbi. Ranija istraživanja s braćom i sestrama (Chambers, 2007; Leutar i sur., 2008; Burke, 2010; Merrick i sur., 2011) ukazuju da su od djetinjstva uključena u skrb o članu s intelektualnim teškoćama, te da preuzimaju skrb nakon smrti roditelja upravo zbog njihovih očekivanja (Bigby, 1998; Davys i sur., 2010). Na primjer, u istraživanju Weeks i sur. (2009) roditelji su otvoreno priznali, baš kao i sudionica ovog istraživanja, da planiraju prepustiti skrb o djetetu s intelektualnim teškoćama djetetu bez intelektualnih teškoća. Međutim, McGrawova i Walkerova (2007) temeljem provedenog istraživanja zaključuju da sestre preuzimaju skrb po uzoru na majke, to jest zbog rodno utemeljene uloge njegovateljice. Doživljeno je i umanjivanje vrijednosti osobe isticanjem obiteljske veze s osobom s intelektualnim teškoćama, na način da član s intelektualnim teškoćama predstavlja temelj identiteta obitelji. Sudionici su identificirani ili članovima obitelji s bolesnim članom ili očevima sramotne djece. Navedenim oblikom stigme se osobu željelo ponizilo, budući da postojanje člana s intelektualnim teškoćama predstavlja devalvirajući status u društvu cijele obitelji. U istraživanju Stalker i Connors (2004) braća su opisala da su bili ismijavani jer imaju braću s intelektualnim teškoćama, te da je identifikacija s njima služila ponižavanju. Također, braća i sestre bila su zbog člana $\mathrm{s}$ intelektualnim teškoćama etiketirana (Moyson i Roeyers, 2012) i stigmatizirana kroz vršnjačko nasilje (Burke, 2004). Rezultati o stigmatizaciji očeva kroz naglašavanje da su im djeca sramotna mogu se objasniti spoznajama istraživanja Pelchat i sur. (2003) prema kojem se očevi više orijentira- ju poslu, te im komparacija djeteta s djecom bez teškoća predstavlja stres povezan s marginalizacijom. U uvodu je navedeno da očevi žele da im dijete bude prepoznato „normalnim“ (Pelchat i sur., 2003; 2009). Rezultati ovog istraživanja ukazuju da je stigma obitelji oca korištena u trenutku sukoba s kolegama na poslu, što dodatno ukazuje da su kolege isticanje očinstva djeteta s intelektualnim teškoćama koristili u svrhu ponižavanja i isticanja svoje pozicije moći jer su očevi djece bez intelektualnih teškoća.

Doživljena je i diskriminacija na radnom mjestu majki djece s intelektualnim teškoćama kroz nemogućnost profesionalnog usavršavanja i degradiranja na radnom mjestu. Navedena diskriminirajuća ponašanja poslodavaca utemeljena su na njihovoj poziciji moći i predrasudi kako zbog skrbi o djetetu s intelektualnim teškoćama zaposlenica ne može doprinositi radnom kolektivu. Doživljeno je i etiketiranje majke radno neupotrebljivom nakon rođenja djeteta s intelektualnim teškoćama. Po rođenju djeteta nerijetko se počinju dovoditi u pitanje kompetencije zaposlenica koje prije nego li su postale majke nisu bile diskriminirane na poslu (Williams i Segal, 2003), dok rezultati istraživanja ukazuju da rođenje djeteta s intelektualnim teškoćama povećava mogućnost isključenja majki iz svijeta rada. Posljednji rezultati ovog istraživanja ukazuju na život u izolaciji. Postoji mogućnost da su upravo svi ranije navedeni oblici stigme obitelji doprinijeli da su obitelji osoba s intelektualnim teškoćama izolirane od svoje okoline. Rezultati ne ukazuju na socijalnu isključenost, već život u izolaciji koji je istovremeno i posljedica i oblik stigme obitelji. Rezultati o nepoželjnosti društva i distanciranju ukazuju da je izolacija posljedica odluke sudionika članova obitelji jer su osjetili da okolina ne želi imati s njima kontakte, dok je distanciranje posljedica ponašanja osoba iz okoline. Gotovo identične rezultate o distanciranju pružaju provedena istraživanja (Lam i MacKanzie; 2002; Hubert, 2010), a razlog može biti to da odrastanjem dijete s intelektualnim teškoćama sve više razlikuje od vršnjaka bez intelektualnih teškoća (Huberrt, 2010). To su naveli i sudionici ovog istraživanja. Izolacija od okoline utvrđeno je iskustvo članova obitelji u mnogim ranijim istraživanjima (Stalker i Connors, 2004; Elford i sur., 2010) budući da su 
obitelji odbačene od rodbine i prijatelja (Carnevale, 2007). S druge strane, majke se izoliraju kako bi zaštitile dijete i sebe od daljnje stigmatizacije i kritiziranja (Azar i Badr, 2006; Hubert, 2010). Život u izolaciji se može dodatno pojasniti i izostankom podrške koji je rezultirao stigmom obitelji kroz prepuštenost samom sebi. Članovi obitelji su i u ranijim istraživanjima naveli prepuštenost samom sebi (Knox i sur., 2000) i izostanak podrške (McConkey i sur., 2008; Pelchat i sur., 2009; Bertelli i sur., 2011; Rillotta i sur., 2012). Izolacija se može temeljiti i na nerazumijevanje obiteljske situacije (Weeks i sur., 2009; Hubert, 2010), dok je niža razina neformalne podrške povezana $s$ višim stupnjem roditeljskog stresa, anksioznosti i depresije (Walden i sur., 2000). Posljednji rezultat ovog istraživanja ukazuje na život u neizvjesnosti. Upravo su neizvjesnost, strah i zabrinutost za budućnost obilježja s kojima žive mnogi članovi obitelji osoba s intelektualnim teškoćama, osobito roditelji (Knox i sur., 2000; Lasseter i sur., 2007; Pelchat i sur., 2009; Weeks i sur., 2009; Ahmed i sur., 2013).

\section{ZAKLJUČAK}

Rezultati ovog istraživanja o stigmi obitelji, dakle stigmatizaciji članova obitelji osoba s različitim stupnjem intelektualnih teškoća, ukazuju kako stanje intelektualnih teškoća člana obitelji negativno utječe na ostale članove obitelji. Članovi obitelji doživljavaju gubitak statusa u društvu. Temeljem obiteljske povezanosti s osobom s intelektualnim teškoćama doživljavaju stigmatizaciju koja je utemeljena na obiteljskoj povezanosti i brizi o osobi $\mathrm{s}$ intelektualnim teškoćama. Stigma obitelji koristi se kako bi se pojedinca ponizilo i umanjilo njegovu vrijednost u socijalnim interakcijama. Intelektualne teškoće su negativno razlikovno obilježje koje utječe na sve članove obitelji. Stigma se temelji na zauzetoj poziciji moći osoba koje stigmatiziraju, što dodatno omogućuje generiranje i utvrđivanje pozicije moći. Stigma intelektualnih teškoća dovodi do umanjivanja statusa u društvu članova cijele obitelji. Navedeno nerijetko rezultira depersonali- zacijom i dehumanizacijom osoba. Kao što ukazuju rezultati istraživanja, nerijetko određeni oblik stigmatizacije rezultira drugim oblikom stigmatizacije, čime se potvrđuje da doživljena stigma generira novu stigmu. Članovi obitelji su u određenim životnim situacijama separirani i izolirani od većine društva. Naime, stigmatizacija dovodi do samoće, dok je samoća određena manifestacija stigme. Nedvojbeno je da su obitelji osoba s intelektualnim teškoćama prisutne u društvu i da koriste resurse društva, međutim rezultati ovog istraživanja ukazuju da obitelji osoba s intelektualnim teškoćama žive u separiranom i nevidljivom društvenom prostoru. Prostoru obilježenim samoćom i prepuštenošću samom sebi. Perspektive članova obitelji o stigmi intelektualnih teškoća ukazuju i na bol kao sastavni dio i posljedicu stigme intelektualnih teškoća. Emocije sudionika temeljem doživljene stigmatizacije ukazuju ponajprije na razočaranje, povrijeđenost i ustupanje.

Skrb o osobi s intelektualnim teškoćama u većini slučajeva članovi obitelji osiguravaju samostalno bez podrške osoba iz okoline, dok ta ista skrb u određenim slučajevima rezultira stigmom obitelji. Temeljem doživljenih iskustava stigme obitelji može se zaključiti da sudionici članovi obitelji osoba s različitim stupnjem intelektualnih teškoća sebe poimaju neuvažavanim, neshvaćenim i osamljenim članovima društva koje im nameće očekivanja, a pruža ograničenu podršku i život u neznanju, diskriminaciji i neizvjesnosti. Članovi obitelji čine podcijenjenu i izoliranu socijalnu grupu u društvu, čiji su životi determinirani stanjem intelektualnih teškoća ili povezanošću s osobom s intelektualnim teškoćama. Stoga bi sustav formalne podrške trebao u većoj mjeri osigurati dodatne oblike podrške obiteljima osoba s intelektualnim teškoćama (npr. grupe podrške, savjetovanje) i usmjeriti se na sustavnu senzibilizaciju društva na potrebe obitelji osoba s intelektualnim teškoćama. Naposljetku, što je to stigma obitelji temeljem intelektualnih teškoća člana obitelji? Sukladno iznesenim perspektivama u rezultatima ovog istraživanja, stigma obitelji je oblik boli i samoće. 


\section{LITERATURA}

Ahmed, S., Bryant, L. D., Ahmed, M., Jafri, H., Raashid, Y. (2013): Experiences of parents with a child with down syndrome in Pakistan and their views on termination of pregnancy. Journal of community genetics, 4, 1, 107-114.

Allen, S. M., Ciambrone, D. (2003): Community care for people with disability: Blurring boundaries between formal and informal caregivers. Qualitative Health Research, 13, 2, 207-226.

Azar, M., Badr, L. K. (2006): The adaptation of mothers of children with intellectual disability in Lebanon. Journal of Transcultural Nursing, 17, 4, 375-380.

Bercker, A. J. (2011): A good and perfect gift. Minnesota: Bethany House Publishers.

Bertelli, M., Bianco, A., Rossi, M., Scuticchio, D., Brown, I. (2011): Relationship between individual quality of life and family quality of life for people with intellectual disability living in Italy. Journal of Intellectual Disability Research, 55, 12, 1136-1150.

Bigby, C. (1998): Parental substitutes: The role of siblings in the lives of older people with intellectual disability. Journal of Gerontological Social Work, 29, 1, 3-21.

Burke, P. (2004): Brothers and sisters of disabled children. London: Jessica Kingsley Publishers.

Burke, P. (2007): Disadvantage and Stigma: A Theoretical Framework for Associated Conditions. U P. Burke, J. Parker (ur.): Social Work and Disadvantage Addressing the Roots of Stigma Through Association (str. 11-26). London: Jessica Kingsley Publisher.

Burke, P., Fell, B. (2007): Childhood Disabilities and Disandvantage: Family Experiences. U: P. Burke, J. Parker (ur.), Social Work and Disadvantage Addressing the Roots of Stigma Through Association (str. 45-62). London: Jessica Kingsley Publisher.

Burke, P. (2010). Brothers and Sisters of Disabled Children: The Experience of Disability by Association. British Journal of Social Work , 40, 1681-1699.

Carnevale, F. A. (2007): Revisiting Goffman's Stigma: the social experience of families with children requiring mechanical ventilation at home. Journal of Child Health Care, 11, 1, 7-18.

Chambers, C. R. (2007): Siblings of individuals with disabilities who enter careers in the disability field. Teacher Education and Special Education: The Journal of the Teacher Education Division of the Council for Exceptional Children, 30, 3, 115-127.

Crabtree, S. A. (2007): Maternal Perceptions of Care-Giving of Children with Developmental Disabilities in the United Arab Emirates. Journal of Applied Research in Intellectual Disabilities, 20, 3, 247-255.

Datta, S. S., Russell, P. S. S., Gopalakrishna, S. C. (2002): Burden among the caregivers of children with intellectual disability associations and risk factors. Journal of Intellectual Disabilities, 6, 4, 337-350.

Davys, D., Mitchell, D., Haigh, C. (2010): Futures planning, parental expectations and sibling concern for people who have a learning disability. Journal of Intellectual Disabilities, 14, 3, 167-183.

Edewor, P. A., Oluremi, H. A., Olujide, A. A. (2010.): Begging to Live: The Strategy of Survival for People with Intellectual Disabilities in Nigeria. U: R.Kober (ur.), Enhanching the Quality of Life of People with Intellectual Disabilities: From Theory to Practice (str. 173-182). New York: Springer.

Edwardraj, S., Mumtaj, K., Prasad, J. H., Kuruvilla, A., Jacob, K. S. (2010): Perceptions about intellectual disability: a qualitative study fromVellore, South India. Journal of Intellectual Disability Research, 54, 8, $736-748$.

Elford, H., Beail, N., Clarke, Z. (2010): 'A very fine line': parents' experiences of using restraint with their adult son/daughter with intellectual disabilities.Journal of Applied Research in Intellectual Disabilities, 23, 1, 75-84. 
Forbat, L., Service, K. P. (2005): Who cares? Contextual layers in end-of-life care for people with intellectual disability and dementia. Dementia, 4, 3, 413-431.

Graff, C., Mandleco, B., Dyches, T. T., Coverston, C. R., Roper, S. O., Freeborn, D. (2012): Perspectives of Adolescent Siblings of Children With Down Syndrome Who Have Multiple Health Problems. Journal of family nursing, 18, 2, 175-199.

Griffith, G. M., Hastings, R. P., Nash, S., Petalas, M., Oliver, C., Howlin, P. Tunnicliffe, P. (2011): "You Have to Sit and Explain it All, and Explain Yourself." Mothers' Experiences of Support Services for Their Offspring with a Rare Genetic Intellectual Disability Syndrome. Journal of genetic counseling, 20, 2, 165-177.

Ho, K. M., Keiley, M. K. (2003): Dealing with denial: a systems approach for family professionals working with parents of individuals with multiple disabilities. The Family Journal, 11, 3, 239-247.

Hsiao, C. Y., Van Riper, M. (2011): Individual and family adaptation in Taiwanese families living with down syndrome. Journal of family nursing, 17, 2, 182-201.

Hubert, J. (2010): 'My heart is always where he is'. Perspectives of mothers of young people with severe intellectual disabilities and challenging behaviour living at home. British Journal of Learning Disabilities, 39, 3, 216-224.

JCHR- Joint Committee on Human Rights. (2008): A Life Like Any Other? Human Rights of Adults with Learning Disabilities. London: The Clerk of the Joint Committee on Human Rights.

Knox, M; (2000). Family control: The views of families who have a child with an intellectual disability. Journal of Applied Research in Intellectual Disabilities, 13, 1, 17-28.

Lam, L. W., Mackenzie, A. E. (2002): Coping with a child with Down syndrome: the experiences of mothers in Hong Kong. Qualitative health research, 12, 2, 223-237.

Lassetter, J. H., Mandleco, B. L., Roper, S. O. (2007): Family Photographs Expressions of Parents Raising Children With Disabilities. Qualitative Health Research, 17, 4, 456-467.

Leutar, Z. Ogresta, J. Milić Babić, M (2008): Obitelji osoba s invaliditetom i mreže podrške. Zagreb: Pravni fakultet.

Link, B. G., Phelan, J. C. (2001): Conceptualizing stigma. Annual review of Sociology, 27, 363-385.

Mandleco, B., Olsen, S. F., Dyches, T., Marshall, E. (2003): The relationship between family and sibling functioning in families raising a child with a disability. Journal of Family Nursing, 9, 4, 365-396.

McConkey, R., Truesdale-Kennedy, M., Chang, M. Y., Jarrah, S., Shukri, R. (2008): The impact on mothers of bringing up a child with intellectual disabilities: A cross-cultural study. International Journal of Nursing Studies, 45, 1, 65-74.

McGraw, L. A., Walker, A. J. (2007): Meanings of Sisterhood and Developmental Disability Narratives From White Nondisabled Sisters. Journal of Family Issues, 28, 4, 474-500.

McHatton, P. A., Correa, V. (2005): Stigma and Discrimination Perspectives From Mexican and Puerto Rican Mothers of Children With Special Needs. Topics in early childhood special education, 25, 3, 131-142.

Merrick, J., Kandel, I., Morad, M. (2011): Parents and Siblings. U: D. R. Patel, D. E. E Greydusan, H. A. Omar, J. Merrick (ur.), Neurodevelopmental Disabilities (str. 463-472). Dordrecht: Springer Netherlands.

Mickelson, K. D. (2001): Perceived Stigma, Social Support, and Depression. Society for Personality and Social Psychology, 27, 8, 1064- 1056.

Moyson, T., Roeyers, H. (2012): 'The overall quality of my life as a sibling is all right, but of course, it could always be better'. Quality of life of siblings of children with intellectual disability: the siblings' perspectives. Journal of Intellectual Disability Research, 56, 1, 87-101. 
Naylor, A., Prescott, P. (2004): Invisible children? The need for support groups for siblings of disabled children. British Journal of Special Education, 31, 4, 199-206.

Pelchat, D., Lefebvre, H., Perreault, M. (2003): Differences and similarities between mothers' and fathers' experiences of parenting a child with a disability. Journal of Child Health Care, 7, 4, 231-247.

Pelchat, D., Levert, M. J., Bourgeois-Guérin, V. (2009): How do mothers and fathers who have a child with a disability describe their adaptation/transformation process?. Journal of Child Health Care, 13, 3, 239-259.

Pietkiewicz, I. Smith, J.A. (2012): Praktyczny przewodnik interpretacyjnej analizy fenomenologicznej w badaniach jakościowych w psychologii. Czasopismo Psychologiczne, 18, 2, 361-369

Power, A. (2008): Caring for independent lives: Geographies of caring for young adults with intellectual disabilities. Social Science Medicine, 67, 5, 834-843.

Reid, K., Flowers, P., Larkin, M. (2005): Exploring lived experience. Psychologist, 18, 1, 20-23.

Richardson, K., Fulton, R. (2011): Dealing with stigma as the parent of a child with disabilities. Carmarthen: Cerebra.

Rillotta, F., Kirby, N., Shearer, J., Nettelbeck, T. (2012): Family quality of life of Australian families with a member with an intellectual/developmental disability. Journal of Intellectual Disability Research, 56, $1,71-86$.

Russell, G., Norwich, B. (2012): Dilemmas, diagnosis and de-stigmatization: Parental perspectives on the diagnosis of autism spectrum disorders. Clinical child psychology and psychiatry, 17, 2, 229-245.

Sarkar, A. (2010). Stigma experienced by parents of adults with intellectual disabilities. Magistarski rad. Ontario: Queen's University Kingston.

Sen, E., Yurtsever, S. (2007): Difficulties experienced by families with disabled children. Journal for Specialists in Pediatric Nursing, 12, 4, 238-252.

Shaw, S. (2009): Problems, problems: You are such a problem! .Journal of Intellectual Disabilities, 13, 2, 99-112.

Smith, J. A. (1996): Beyond the divide between cognition and discourse: Using interpretative phenomenological analysis in health psychology. Psychology and health, 11, 2, 261-271.

Smith, J.A. i Osborn, M. (2003): Interpretative phenomenological analysis U: J. A. Smith (ur.,), Qualitative Psychology: A Practical Guide to Research Methods (str. 51-80). London: Sage Publications.

Smith, J. A., Osborn, M. (2008): Interpretative Phenomenological Analysis. U: J. A. Smith (ur.). Qualitative psychology: A practical guide to research methods (Second edition) (str.53-80. London: Sage.

Stalker, K., Connors, C. (2004): Children's perceptions of their disabled siblings:'she's different but it's normal for us'. Children Society, 18, 3, 218-230.

Tam, S., Cheng, A. W. Y. (2005): Self-concepts of parents with a child of school age with a severe intellectual disability. Journal of Intellectual Disabilities, 9, 3, 253- 268.

Wagner Jakab, A., Cvitković, D., Hojanić, R. (2006): Neke značajke odnosa sestara/braće i osoba s posebnim potrebama. Hrvatska revija za rehabilitacijska istraživanja, 42, 1, 77-86.

Walden, S., Pistrang, N., Joyce, T. (2000): Parents of adults with intellectual disabilities: Quality of life and experiences of caring. Journal of Applied Research in Intellectual Disabilities, 13, 2, 62-76.

Weeks, L. E., Nilsson, T., Bryanton, O., Kozma, A. (2009): Current and future concerns of older parents of sons and daughters with intellectual disabilities. Journal of Policy and Practice in Intellectual Disabilities, 6, 3, 180-188. 
Westerholm, R. I., Radak,L., Keys, C. B., Henry, D. B. (2006): Stigma. U: G. L. Albrecht (ur.), Encyclopedia of Disability (str. 1502- 1506). Thousands Oaks: Sage.

Williams, J. C., Segal, N. (2003): Beyond the maternal wall: Relief for family caregivers who are discriminated against on the job. Harvard Women's Law Journal, 26, 77.

Yang, L. H., Kleinman, A., Link, B. G., Phelan, J. C., Lee, S., Good, B. (2007): Culture and stigma: adding moral experience to stigma theory. Social science medicine, 64, 7, 1524-1535.

\section{„THEY USED TO TELL ME THAT I'M NO BETTER THAN MY SON“- FAMILY STIGMA BASED ON INTELLECTUAL DISABILITY OF A FAMILY MEMBER}

\footnotetext{
Abstract: This paper is about family stigma arising from the intellectual disability of a family member. The aim of this study was to obtain insight into the perspectives of family members of people with various types of intellectual disabilities about family stigma. The research question was 'How do family members of people with intellectual disabilities experience family stigma?' This study was conducted on a purposive sample of 22 family members of people with different types of intellectual disability (10 mothers, three fathers, two sisters, five brothers, one grandmother and one grandfather). At the time of the study, they were all living in Zagreb, and their family members with intellectual disabilities were members of different associations or institutions for people with intellectual disabilities. The semi-structured interview was the method in this qualitative research. Interpretative phenomenological analysis was used as the data analysis method. The findings about family stigma indicated pity, mothers being blamed, imposed expectations and responsibilities on brothers and sisters, devaluation of the person based on having a family member with intellectual disability, work discrimination of mothers who have children with intellectual disability, and isolation. These results confirm earlier findings from different studies about the family stigma of intellectual disability, specifically with respect to loss of status in society and social devaluation of the family. Family stigma due to intellectual disability results in feelings of loneliness and emotional pain.
}

Key words: family stigma; family members of people with intellectual disability; loss of status in society 